\title{
Relationship between long-term coffee consumption and components of the metabolic syndrome: the Amsterdam Growth and Health Longitudinal Study
}

\author{
Lisanne Balk $\cdot$ Trynke Hoekstra $\cdot$ Jos Twisk
}

Received: 6 June 2008/Accepted: 23 February 2009/Published online: 10 March 2009

(c) The Author(s) 2009. This article is published with open access at Springerlink.com

\begin{abstract}
Cardiovascular diseases and diabetes mellitus type II (DM II) are both major health problems. A large risk factor for these diseases is the presence of the metabolic syndrome. It is known that the risk of DM II can be decreased by coffee consumption. Therefore, we examined the association between coffee consumption and the components of the metabolic syndrome. Prospective data from the Amsterdam Growth and Health Longitudinal Study (AGAHLS) is used to analyse the associations between coffee consumption (averaged over a period from 27 till 42 years) and the components of the metabolic syndrome (at the age of 42 years). This was done by linear regression analyses and associations were adjusted for physical activity, energy intake, alcohol consumption and smoking behaviour. The results showed that moderate and high $(>2$ cups/day) coffee consumption was significantly associated with lower HDL in women. For men, coffee consumption was not associated with any of the components of the metabolic syndrome.
\end{abstract}

Keywords Cardiovascular disease - Coffee consumption - Diabetes mellitus - Metabolic syndrome · Risk factors · Longitudinal study

L. Balk · T. Hoekstra $\cdot$ J. Twisk

Institute of Health Sciences, VU University, Amsterdam,

The Netherlands

\section{J. Twisk $(\bowtie)$}

Department of Clinical Epidemiology and Biostatistics,

VU Medical Centre, de Boelelaan 1118,

1081 HV Amsterdam, The Netherlands

e-mail: jwr.twisk@vumc.nl

\section{Background}

Cardiovascular diseases (CVD) and diabetes mellitus type II (DM II) are both major health problems and considerate research has been carried out to assess the determinants of these diseases [1-5]. A very important risk factor for these diseases is the 'metabolic syndrome' [6, 7]. This consists of five components; (1) elevated blood pressure, (2) low HDL cholesterol levels, (3) high triglyceride levels, (4) high fasting glucose levels and (5) abdominal obesity. When three or more of five of the components are present, metabolic syndrome is diagnosed $[8,9]$.

The presence of the metabolic syndrome is associated with an approximately two-fold elevation in the risk of fatal CVD in men and nonfatal CVD in women [6]. A threefold increase in risk for coronary heart disease and stroke and a marked increase in cardiovascular mortality in subjects with the metabolic syndrome were also reported [7]. The main causes of the metabolic syndrome are overweight/obesity, genetic factors and lifestyle factors such as physical activity, nutrition, smoking behaviour and alcohol consumption [9-12]. However, one lifestyle aspect which has not been studied often in relation to the metabolic syndrome is coffee consumption, even though coffee is one of the most consumed beverages in the world [13].

The effects of coffee consumption on human health and in particular the components of the metabolic syndrome, are found to be inconsistent [3, 14-18]. Most of these studies however, focused on short term effects of coffee consumption. Therefore, in the present study the associations between long term coffee consumption and the components of the metabolic syndrome were investigated.

All analyses were performed with the use of data from the Amsterdam Growth and Health Longitudinal Study (AGAHLS). 


\section{Methods}

Study design and subjects

The Amsterdam Growth and Health Longitudinal Study (AGAHLS) is an observational longitudinal study that began in 1976 with a group of 450 boys and girls. Its initial goals were to describe the natural development of growth, health and lifestyle of adolescents and to investigate longitudinal relationships between biological and lifestyle variables. The mean $\pm \mathrm{SD}$ age of the subjects at the beginning of the study was $13.1 \pm 0.8$ years. Since then, a series of examinations have been performed during a 30year follow-up period, collecting data on anthropometric (body height, body weight, and skin folds), biological (serum lipoprotein levels, blood pressure and physical fitness), lifestyle (nutritional habits, smoking behaviour, and daily physical activity), and psychological variables [19].

In the most recent measurement period (2006) at the age of 42 years, the five components of the metabolic syndrome, according to the current guidelines [8], were measured in 344 subjects. The coffee consumption of the subjects was measured at the ages of 27, 29, 32, 36 and 42 years. Subjects who missed data of two or more measurements on coffee consumption were excluded from the analyses.

The study was approved by the medical ethical committee of the VU University Medical Centre and all subjects gave their written informed consent.

Metabolic syndrome and its components

Blood pressure was measured in a supine position with an automated device (Dinamap Procare 100), at 5-min intervals, for $60 \mathrm{~min}$. For blood pressure as a continuous variable, the Mean Arterial Pressure (MAP) was calculated as $(2 *$ diastolic blood pressure +1 *systolic blood pressure) $/ 3$ [20]. High-density lipoprotein (and total) cholesterol, triglycerides and fasting blood glucose levels were measured by enzymatic techniques (Roche Diagnostics, Mannheim, Germany). Waist circumference was measured with a flexible steel tape (Martin circumeter; Franken \& Itallie) at the level midway between the lowest rib margin and the iliac crest [21].

The identification of the metabolic syndrome and its components was based on a slightly modified version of the definition proposed by the National Cholesterol Education Program (NCEP) Adult Treatment Panel III $[8,9]$, i.e., when three or more of the following five risk factors were present: (1) a systolic blood pressure of $130 \mathrm{mmHg}$ or higher and/or a diastolic blood pressure of $85 \mathrm{mmHg}$ or higher; (2) a high-density lipoprotein cholesterol level of less than $1.03 \mathrm{mmol} / \mathrm{l}$ in men and less than $1.29 \mathrm{mmol} / \mathrm{l}$ in women; (3) a triglyceride level of $1.69 \mathrm{mmol} / \mathrm{l}$ or more; (4) a fasting plasma glucose levels of $6.1 \mathrm{mmol} / \mathrm{l}$ or more; and (5) a waist circumference of more than $94 \mathrm{~cm}$ in men and more than $80 \mathrm{~cm}$ in women, ie, more liberal cut off values then originally proposed $(>102 \mathrm{~cm}$ in men and $>88 \mathrm{~cm}$ in women), since they may be more appropriate in the identification of individuals at increased risk in young and apparently healthy populations $[9,21]$.

\section{Coffee consumption}

Coffee consumption was measured with a questionnaire at the ages of 27, 29, 32, 36 and 42 years. In the questionnaires, it was asked for how many cups of coffee a subject drinks during weekdays and how many cups of coffee a subject drinks during weekend days. Furthermore a distinction was made between caffeinated and decaffeinated coffee consumption. The average coffee consumption over the total measurement period was calculated by taking the mean of the three, four or five coffee intake measurements and is expressed in cups/day. In the analyses, no distinction was made between the types of coffee (filtered, boiled, instant, pads) and between caffeinated and decaffeinated coffee.

\section{Covariates}

The relationship between components of the metabolic syndrome and coffee consumption can be influenced by other lifestyle components [11, 22]. Consequently, possible confounding factors, such as physical activity, energy intake, alcohol consumption and smoking behaviour were taken into consideration.

Physical activity was assessed with a validated interview and is expressed in MET*min/week. For physical activity, year specific z-scores were calculated and the values were averaged over the period from the age of 27 till 36 years. Energy intake was measured with a cross-check dietary interview in which the subjects were asked to recall their usual dietary intake during the previous month. Frequency, amounts and methods of preparation of the foods and drinks consumed were reported and values are expressed in $\mathrm{kcal} /$ day. Year specific z-scores were calculated for energy intake and the values were averaged over the period from the age of 27 till 36 years. The dietary interview also provided information about alcohol consumption and the amount of alcohol consumed (in glasses/week) at the age of 42 years was obtained. Smoking was measured with a tobacco questionnaire and was divided into three groups (smokers, non-smokers and subjects who have smoked in the past, but not anymore).

More detailed information of the methods used in the AGAHLS can be found elsewhere [19]. 
Statistical analysis

To examine the associations between coffee consumption (averaged over the period from the age of 27 to 42 years) and the five components of the metabolic syndrome at the age of 42 years, linear regression analyses were used. In men, the average coffee consumption between the ages of 27 and 42 years was categorized in four groups $(\leq 2,>2$ and $\leq 4,>4$ and $\leq 6,>6 \mathrm{cups} /$ day). Coffee consumption in women was categorized in three groups $(\leq 2,>2$ and $\leq 4$, $>4$ cups/day) instead of four, as the highest category $(>6$ cups/day) was combined with the second highest category ( $>4$ and $\leq 6$ ), given that the group size of the highest category on its own was too small. The categorical variable was represented in the regression analyses by dummy variables, where the lowest category ( $\leq 2$ cups/day) was used as the reference category. This (standard) approach results in regression coefficients indicating the difference in a particular outcome variable between the groups with a different amount of coffee consumption.

Of the outcome variables, triglyceride and fasting blood glucose were not normally distributed and these variables were logarithmically transformed to correspond with the assumptions of regression analysis. All analyses were performed separately for men and women. Besides the crude analyses, an adjustment for physical activity, energy intake, alcohol consumption and smoking was performed.

To evaluate main effects, a 5\% significance level was assumed. All statistical analyses were performed with SPSS 14.0.

\section{Results}

Table 1 shows the characteristics of the population, stratified by gender. Average coffee consumption for men was 4.5 cups/day, for women 3.1 cups/day.

Table 2 shows the prevalence of the metabolic syndrome and its components. The prevalence of the metabolic syndrome at the age of 42 years in the entire population was only $3.5 \%$ (around $8 \%$ for men and $0 \%$ for women).

Table 3 presents the results of the regression analyses, showing the effect of 15 years of coffee consumption on the five components of the metabolic syndrome at the age of 42 for men. The crude analyses show no significant effect for any of the variables. In the adjusted model (adjusted for physical activity, energy intake, smoking behaviour and alcohol consumption) no significant effects were found either.

Table 4 presents the results of the same analyses as Table 3, only for women. The crude analyses show some borderline significant effects for HDL. It seems that a moderate coffee consumption ( $>2$ and $\leq 4$ cups/day), as
Table 1 Mean and standard deviation (between brackets) of subject characteristics at the age of 42 years (measured in 2006)

\begin{tabular}{|c|c|c|}
\hline & $\begin{array}{l}\text { Men } \\
(N=123)\end{array}$ & $\begin{array}{l}\text { Women } \\
(N=160)\end{array}$ \\
\hline Coffee total, cups/day & $4.5(2.5)$ & $3.1(1.9)$ \\
\hline$\leq 2$, no $(\%)$ & $19(15.4)$ & $48(30)$ \\
\hline$>2$ and $\leq 4$, no $(\%)$ & $32(26.0)$ & $62(38.1)$ \\
\hline$>4$ and $\leq 6$, no $(\%)$ & $47(38.2)$ & $42(26.3)$ \\
\hline$>6$, no $(\%)$ & $25(20.3)$ & $9(5.6)$ \\
\hline Systolic blood pressure & $122.2(13.6)$ & $110.9(12.6)$ \\
\hline Diastolic blood pressure & $72.8(7.7)$ & $67.8(7.9)$ \\
\hline Mean arterial pressure $(\mathrm{mmHg})^{\mathrm{a}}$ & $89.3(9.0)$ & $82.2(9.0)$ \\
\hline HDL (mmol/l) & $1.5(0.3)$ & $1.9(0.4)$ \\
\hline Triglycerides (mmol/l) & $1.4(1.1)$ & $1.0(0.4)$ \\
\hline Fasting glucose $(\mathrm{mmol} / \mathrm{l})$ & $5.2(1.1)$ & $4.9(0.5)$ \\
\hline Waist circumference $(\mathrm{cm})$ & $89.3(8.1)$ & $77.6(8.6)$ \\
\hline Physical activity (Mets/week) ${ }^{\mathrm{b}}$ & $3604(2190)$ & 3931 (1937) \\
\hline Energy intake $(\mathrm{Kcal} / \mathrm{day})^{\mathrm{b}}$ & $2937(636)$ & 2257 (419) \\
\hline $\begin{array}{l}\text { Alcohol consumption (glass/ } \\
\text { week) })^{c}\end{array}$ & $6.3(1.9-13.8)$ & $1.9(0.6-6.3)$ \\
\hline \multicolumn{3}{|l|}{ Smoking behaviour } \\
\hline Never, no $(\%)$ & $69(56.1)$ & $98(61.3)$ \\
\hline Past, no (\%) & $32(26.0)$ & $43(26.8)$ \\
\hline Current, no (\%) & $22(17.9)$ & 19 (11.9) \\
\hline \multicolumn{3}{|c|}{$\begin{array}{l}\text { a Calculated as }(2 * \text { diastolic blood pressure }+ \text { systolic blood pres } \\
\text { sure }) / 3\end{array}$} \\
\hline
\end{tabular}

Table 2 Prevalence of the components metabolic syndrome

\begin{tabular}{lcl}
\hline Risk factor & $\begin{array}{l}\text { Men } \\
(N=123)\end{array}$ & $\begin{array}{l}\text { Women } \\
(N=160)\end{array}$ \\
\hline $\begin{array}{l}\text { Blood pressure }(\geq 130 / 85 \mathrm{mmHg}) \\
\text { HDL }(<1.03 \mathrm{mmol} / \mathrm{l}, \mathrm{men} ;\end{array}$ & $26(21.2 \%)$ & $16(10.0 \%)$ \\
$\quad<1.29 \mathrm{mmol} / \mathrm{l}$, women $)$ & $30(5.7 \%)$ & $8(5.0 \%)$ \\
Triglycerides $(\geq 1.69 \mathrm{mmol} / \mathrm{l})$ & $8(6.5 \%)$ & $3(1.9 \%)$ \\
Fasting blood glucose $(\geq 6.1 \mathrm{mmol} / \mathrm{l})$ & $33(26.8 \%)$ & $48(30 \%)$ \\
$\begin{array}{l}\text { Waist circumference }(>94 \mathrm{~cm}, \mathrm{men} ; \\
\quad>80 \mathrm{~cm}, \text { women })\end{array}$ & $10(8.1 \%)$ & 0 \\
Metabolic syndrome $^{\mathrm{a}}$ & & $8(5.0 \%)$ \\
\hline
\end{tabular}

a 3 (or more) of 5 components

well as a high coffee consumption ( $>4$ cups/day) decreases HDL levels. Although, these effects are just above the 5\% significance level $(P=0.06)$. Adjustment for physical activity, energy intake, smoking behaviour and alcohol consumption, strengthened these associations. Furthermore, MAP appears to decrease with a moderate coffee consumption ( $>2$ and $\leq 4$ cups/day), although, this effect was only borderline significant. For all other components, no significant effects were found. 
Table 3 Effect (95\% confidence interval) of coffee consumption on components of the metabolic syndrome for men

\begin{tabular}{|c|c|c|c|c|}
\hline & \multicolumn{4}{|c|}{ Coffee consumption (cups/day) } \\
\hline & $>2$ and $\leq 4$ & $>4$ and $\leq 6$ & $>6$ & $\begin{array}{l}P \text { for } \\
\text { trend }\end{array}$ \\
\hline \multicolumn{5}{|l|}{ Crude analysis } \\
\hline Mean arterial pressure $(\mathrm{mmHG})^{\mathrm{a}}$ & $\begin{array}{l}-3.7(-8.9 \text { to } 1.5) \\
P=0.16\end{array}$ & $\begin{array}{l}-3.6(-8.5 \text { to } 1.3) \\
P=0.15\end{array}$ & $\begin{array}{l}-0.3(-5.8 \text { to } 5.3) \\
P=0.93\end{array}$ & 0.95 \\
\hline $\mathrm{HDL}(\mathrm{mmol} / \mathrm{l})^{\mathrm{a}}$ & $\begin{array}{l}0.01(-0.19 \text { to } 0.21) \\
P=0.90\end{array}$ & $\begin{array}{l}0.04(-0.15 \text { to } 0.22) \\
P=0.68\end{array}$ & $\begin{array}{l}-0.05(-0.25 \text { to } 0.16) \\
P=0.66\end{array}$ & 0.59 \\
\hline Triglyceride $(\mathrm{mmol} / \mathrm{l})^{\mathrm{b}}$ & $\begin{array}{l}1.07(0.76 \text { to } 1.51) \\
P=0.68\end{array}$ & $\begin{array}{l}1.03(0.75 \text { to } 1.40) \\
P=0.87\end{array}$ & $\begin{array}{l}1.19(0.84 \text { to } 1.70) \\
P=0.34\end{array}$ & 0.44 \\
\hline Fasting glucose $(\mathrm{mmol} / \mathrm{l})^{\mathrm{b}}$ & $\begin{array}{l}1.01(0.92 \text { to } 1.09) \\
P=0.91\end{array}$ & $\begin{array}{l}1.03(0.95 \text { to } 1.12) \\
P=0.46\end{array}$ & $\begin{array}{l}1.03(0.94 \text { to } 1.12) \\
P=0.50\end{array}$ & 0.36 \\
\hline Waist circumference $(\mathrm{cm})^{\mathrm{a}}$ & $\begin{array}{l}0.7(-4.0 \text { to } 5.3) \\
P=0.78\end{array}$ & $\begin{array}{l}0.4(-4.0 \text { to } 4.8) \\
P=0.87\end{array}$ & $\begin{array}{l}2.5(-2.4 \text { to } 7.4) \\
P=0.32\end{array}$ & 0.37 \\
\hline \multicolumn{5}{|l|}{ Adjusted analysis $^{c}$} \\
\hline Mean arterial pressure $(\mathrm{mmHG})^{\mathrm{a}}$ & $\begin{array}{l}-5.2(-10.6 \text { to } 0.2) \\
P=0.06\end{array}$ & $\begin{array}{l}-4.7(-9.8 \text { to } 0.4) \\
P=0.07\end{array}$ & $\begin{array}{l}-1.4(-7.0 \text { to } 4.3) \\
P=0.06\end{array}$ & 0.90 \\
\hline $\mathrm{HDL}(\mathrm{mmol} / \mathrm{l})^{\mathrm{a}}$ & $\begin{array}{l}0.02(-0.19 \text { to } 0.22) \\
P=0.87\end{array}$ & $\begin{array}{l}0.05(-0.14 \text { to } 0.24) \\
P=0.62\end{array}$ & $\begin{array}{l}-0.05(-0.26 \text { to } 0.16) \\
P=0.61\end{array}$ & 0.68 \\
\hline Triglyceride $(\mathrm{mmol} / \mathrm{l})^{\mathrm{b}}$ & $\begin{array}{l}1.03(0.73 \text { to } 1.46) \\
P=0.85\end{array}$ & $\begin{array}{l}0.93(0.67 \text { to } 1.30) \\
P=0.68\end{array}$ & $\begin{array}{l}1.12(0.78 \text { to } 1.61) \\
P=0.53\end{array}$ & 0.71 \\
\hline Fasting glucose $(\mathrm{mmol} / \mathrm{l})^{\mathrm{b}}$ & $\begin{array}{l}1.00(0.92 \text { to } 1.09) \\
P=0.94\end{array}$ & $\begin{array}{l}1.01(0.94 \text { to } 1.10) \\
P=0.72\end{array}$ & $\begin{array}{l}1.02(0.93 \text { to } 1.11) \\
P=0.72\end{array}$ & 0.59 \\
\hline Waist circumference $(\mathrm{cm})^{\mathrm{a}}$ & $\begin{array}{l}0.5(-4.4 \text { to } 5.5) \\
P=0.84\end{array}$ & $\begin{array}{l}0.2(-4.5 \text { to } 4.8) \\
P=0.95\end{array}$ & $\begin{array}{l}2.3(-2.8 \text { to } 7.4) \\
P=0.37\end{array}$ & 0.42 \\
\hline
\end{tabular}

${ }^{a}$ Effect is difference in average value with reference category $\leq 2$ cups/day

${ }^{\mathrm{b}}$ Effect is ratio in average value with reference category $\leq 2$ cups/day

c Adjusted for energy intake, physical activity, smoking and alcohol consumption

The effect of coffee consumption on HDL appeared to be significant in women, but not in men. However, it should be noted that the difference in the relationship of HDL and coffee consumption between men and women was not statistically significant, given the overlapping confidence intervals.

To explore the relationship between coffee consumption and HDL in women a bit further, we first added body mass index (BMI) to the model to investigate whether the relationship between coffee consumption and HDL was mediated by BMI. This was not the case; the results of the analyses did not change (data not shown). In a second explorative analysis, a multiple regression analyses was performed in which coffee consumption was analysed in combination with BMI, waist circumference, physical activity, smoking behaviour and alcohol consumption. Table 5 shows the results of this multiple regression analysis. Also in this multiple regression model, coffee consumption remains (significantly) related to HDL, while also alcohol consumption (the more glasses/week, the higher HDL levels) and waist circumference (the higher waist circumference, the lower HDL levels) were significantly associated with HDL.

\section{Discussion}

This study examined the association between coffee consumption and the components of the metabolic syndrome in a relatively healthy Dutch study population. It appeared that coffee consumption was inversely associated with HDL level in women. A significant, inverse relation between coffee consumption and HDL was found. Furthermore, an almost significant inverse association was found between average coffee consumption and MAP, and for men, waist circumference seems to be somewhat associated with a high coffee consumption.

In the present study, an inverse association was found between HDL level and average/high coffee consumption in women. A meta-analysis of randomized controlled trials (RCT) regarding associations between coffee consumption and cholesterol, showed that consuming 6 cups/day was 
Table 4 Effect (95\% confidence interval) of coffee consumption on components of the metabolic syndrome for women

\begin{tabular}{|c|c|c|c|}
\hline & \multicolumn{3}{|c|}{ Coffee consumption (cups/day) } \\
\hline & $>2$ and $\leq \leq 4$ & $>4$ & $P$ for trend \\
\hline \multicolumn{4}{|l|}{ Crude analysis } \\
\hline Mean arterial pressure $(\mathrm{mmHG})^{\mathrm{a}}$ & $\begin{array}{l}-3.0(-6.5 \text { to } 0.4) \\
P=0.08\end{array}$ & $\begin{array}{l}0.1(-3.5 \text { to } 3.7) \\
P=0.96\end{array}$ & 0.94 \\
\hline $\mathrm{HDL}(\mathrm{mmol} / \mathrm{l})^{\mathrm{a}}$ & $\begin{array}{l}-0.15(-0.30 \text { to } 0.01) \\
P=0.06\end{array}$ & $\begin{array}{l}-0.15(-0.31 \text { to } 0.01) \\
P=0.06\end{array}$ & 0.06 \\
\hline Triglyceride $(\mathrm{mmol} / \mathrm{l})^{\mathrm{b}}$ & $\begin{array}{l}1.01(0.87 \text { to } 1.17) \\
P=0.90\end{array}$ & $\begin{array}{l}1.04(0.89 \text { to } 1.22) \\
P=0.59\end{array}$ & 0.58 \\
\hline Fasting glucose $(\mathrm{mmol} / \mathrm{l})^{\mathrm{b}}$ & $\begin{array}{l}1.03(0.99 \text { to } 1.07) \\
P=0.16\end{array}$ & $\begin{array}{l}1.01(0.97 \text { to } 1.05) \\
P=0.54\end{array}$ & 0.58 \\
\hline Waist circumference $(\mathrm{cm})^{\mathrm{a}}$ & $\begin{array}{l}1.4(-1.9 \text { to } 4.7) \\
P=0.41\end{array}$ & $\begin{array}{l}2.5(-1.0 \text { to } 5.9) \\
P=0.16\end{array}$ & 0.16 \\
\hline \multicolumn{4}{|l|}{ Adjusted analysis $^{c}$} \\
\hline Mean arterial pressure $(\mathrm{mmHG})^{\mathrm{a}}$ & $\begin{array}{l}-3.1(-6.7 \text { to } 0.5) \\
P=0.09\end{array}$ & $\begin{array}{l}-0.1(-3.8 \text { to } 3.7) \\
P=0.97\end{array}$ & 0.95 \\
\hline $\mathrm{HDL}(\mathrm{mmol} / \mathrm{l})^{\mathrm{a}}$ & $\begin{array}{l}-0.18(-0.34 \text { to }-0.02) \\
P=0.03\end{array}$ & $\begin{array}{l}-0.20(-0.36 \text { to }-0.03) \\
P=0.02\end{array}$ & 0.03 \\
\hline Triglyceride $(\mathrm{mmol} / \mathrm{l})^{\mathrm{b}}$ & $\begin{array}{l}0.98(0.83 \text { to } 1.14) \\
P=0.75\end{array}$ & $\begin{array}{l}1.05(0.90 \text { to } 1.24) \\
P=0.53\end{array}$ & 0.59 \\
\hline Fasting glucose $(\mathrm{mmol} / \mathrm{l})^{\mathrm{b}}$ & $\begin{array}{l}1.02(0.99 \text { to } 1.07) \\
P=0.20\end{array}$ & $\begin{array}{l}1.01(0.97 \text { to } 1.05) \\
P=0.61\end{array}$ & 0.75 \\
\hline Waist circumference $(\mathrm{cm})^{\mathrm{a}}$ & $\begin{array}{l}1.36(-2.4 \text { to } 4.9) \\
P=0.44\end{array}$ & $\begin{array}{l}2.6(-1.1 \text { to } 6.3) \\
P=0.17\end{array}$ & 0.17 \\
\hline
\end{tabular}

${ }^{a}$ Effect is difference in average value with reference category $\leq 2$ cups/day

b Effect is ratio in average value with reference category $\leq 2$ cups/day

c Adjusted for energy intake, physical activity, smoking and alcohol consumption

Table 5 Results of a multiple regression analysis to explore the effect of coffee consumption and other risk factors on HDL in women

\begin{tabular}{lcc}
\hline & Effect $(95 \%$ CI $)$ & $P$-value \\
\hline Coffee consumption $^{\mathrm{a}}$ & & \\
$>2$ and $\leq 4$ cups/day & $-0.17(-0.32$ to -.02$)$ & 0.03 \\
$>4$ cups/day & $-0.15(-0.31$ to 0.00$)$ & 0.06 \\
$\begin{array}{l}\text { Alcohol consumption } \\
\quad \text { glasses/week) }\end{array}$ & $0.02(0.01$ to 0.03$)$ & 0.01 \\
$\quad \begin{array}{l}\text { Physical activity } \\
\text { Waist circumference }\end{array}$ & $-0.02(-0.06$ to 0.09$)$ & 0.70 \\
$\quad$ Body mass index & $0.01(-0.04$ to -0.01$)$ & 0.02 \\
Smoking behaviour & \\
Past & $0.04)$ & 0.61 \\
Current & $-0.08(-0.27$ to 0.12$)$ & 0.45 \\
\hline
\end{tabular}

a $\leq 2$ Cups/day is used as reference category

b Never smokers is used as reference category

associated with increased LDL cholesterol, but not with HDL. A distinct difference in outcome in blood cholesterol levels appeared between boiled coffee and filtered coffee.
Increases in serum lipids (except for HDL) were greater in studies where people drank boiled coffee [16]. These differences in effect on blood cholesterol between filtered and unfiltered/boiled coffee were found in several other studies as well [23-25]. However, at least one trial using filtered coffee, has shown that coffee consumption was associated with an increase in total serum cholesterol [26]. The cholesterol raising factors in boiled coffee are cafestol and kahweol. Two fat-soluble matters, which are originally present in coffee oil. In particular cafestol is found to raise blood cholesterol [27]. The population in the present study drank mostly drip-filtered caffeinated coffee, which does not contain cafestol and kahweol.

Regarding waist circumference, positive associations were found in both male and female subjects with a high coffee consumption. However, these associations were not statistically significant. To our knowledge there are almost no studies reporting a relationship between coffee consumption and waist circumference. However, many studies investigate the relationship between coffee consumption and body mass index as indicator for body fatness. Positive 
associations between coffee consumption and body mass index (BMI) were found in several studies [13, 28, 29]. However, also contrary effects were found. In a prospective study over a period of 12 years, it appeared that an increase in caffeine intake, mainly due to coffee consumption, led to a small reduction in long-term weight gain [30].

In the present study, triglycerides were not associated with coffee consumption in either men or women. Contradictory to this outcome, a meta-analysis of RCT's reported a dose-response relation between coffee consumption and triglycerides [16]. On the other hand, a longitudinal study in Japan showed that triglyceride levels were significantly and inversely associated with coffee consumption [18].

In the present study, blood pressure was to some extent inversely associated with moderate coffee consumption. Comparable to this outcome, an inverse association between coffee and blood pressure was found in a study in a general Norwegian population [14]. However, in previous studies it has been suggested that coffee raises blood pressure. A meta-analysis of RCT's revealed a significant association between coffee consumption and both systolic and diastolic blood pressure [15]. In a more recent metaanalysis it was suggested that caffeine, when ingested through coffee, either has a very small, or no effect on blood pressure [31]. This finding is supported by many single studies as well [32-35].

For fasting blood glucose, no associations with coffee consumption were found in the present study. There are numerous studies, which claim positive health effects of coffee consumption on diabetes mellitus type II or insulin resistance. Several studies conclude that caffeine intake, mainly due to coffee consumption, can reduce risk of DM II and reduce insulin resistance [3, 13, 30, 36, 37]. The present study does not support these outcomes. However, also in a study in which a reduced risk of DM II was found due to high coffee consumption, no association between high coffee consumption and fasting plasma glucose levels was found [38]. On the other hand, Keyzers found an inverse relationship between insulin sensitivity and caffeine in healthy humans [39]. This effect however, was a short-term effect and was as a result of just (intravenous) caffeine intake instead of coffee intake.

\section{Limitations}

Although this study is probably one of the first in which long term coffee consumption is related to health outcomes, a few limitations should be mentioned. This study was supposed to examine the association between long term coffee consumption and the metabolic syndrome. However, the prevalence of the metabolic syndrome in our study population was only $3.5 \%$ (around $8 \%$ for men and
$0 \%$ for women) so it was not possible to analyze this relationship. This prevalence of the metabolic syndrome in our study population was extremely low, compared to the prevalence of the metabolic syndrome for adults in the Netherlands (15-22\% for men and $9-15 \%$ for women) [40].

There are several reasons for not finding strong effects of coffee consumption on the components of the metabolic syndrome. First, as mentioned before, the study population was relatively healthy. Besides the low prevalence for the metabolic syndrome, the population seemed to be healthy for the separate components as well (see Table 2). Furthermore, it was not possible to take coffee additives as milk, cream and sugar into consideration. Although these variables were not included in our analyses, adjustments were made for energy intake (kcal/day). Besides this, the average coffee consumption in the population was $4.5 \mathrm{cups} /$ day for men and $3.1 \mathrm{cups} /$ day for women. These averages are relatively low compared to existing literature, while it is known that especially the higher coffee consumption ( $>6$ or $>7$ cups/day) shows the largest effects [3]. Especially in women, the highest coffee category was extremely small and had to be combined with the second highest category.

In conclusion, 15 years of coffee consumption was inversely associated with HDL and with MAP (the latter only for moderate coffee consumption) for women. For men, no significant associations were found between long term coffee consumption and metabolic syndrome risk factors.

Open Access This article is distributed under the terms of the Creative Commons Attribution Noncommercial License which permits any noncommercial use, distribution, and reproduction in any medium, provided the original author(s) and source are credited.

\section{References}

1. Hu FB, van Dam RM, Liu S. Diet and risk of type II DM: the roles of type of fat and carbohydrate. Diabetologia. 2001;44:80517.

2. Hu G, Tuomilehto J, Silventoinen K, Barengo N, Jousilahti P. Joint effects of physical activity, body mass index, waist circumference and waist-to-hip ratio with the risk of cardiovascular disease among middle-aged Finnish men and women. Eur Heart J. 2004;25:2212-9.

3. van Dam RM, Hu FB. Coffee consumption and risk of type 2 diabetes: a systematic review. JAMA. 2005;294:97-104.

4. Haapanen-Niemi N, Miilunpalo S, Pasanen M, Vuori I, Oja P, Malmberg J. Body mass index, physical inactivity and low level of physical fitness as determinants of all cause and cardiovascular disease mortality - 16 year follow-up of middle-aged and elderly men and women. Int J Obes. 2000;24:1465-74.

5. Wilson PW, D'Agostino RB, Sullivan L, Parise H, Kannel WB. Overweight and obesity as determinants of cardiovascular risk. Arch Intern Med. 2002;162:1867-72. 
6. Dekker JM, Girman C, Rhodes T, Nijpels G, Stehouwer CD, Bouter LM, et al. Metabolic syndrome and 10-year cardiovascular disease risk in the Hoorn study. Circulation. 2005;112:666-73.

7. Isomaa B, Almgren P, Tuomi T, Forsén B, Lahti K, Nissén M, et al. Cardiovascular morbidity and mortality associated with the metabolic syndrome. Diabetes Care. 2001;24:683-9.

8. Grundy SM, Brewer HB, Cleeman JI, Smith SC, Lenfant C. Definition of metabolic syndrome: report of the national heart, lung and blood institute/American heart association conference on scientific issues related to definition. Arterioscler Thromb Vasc Biol. 2004;24:e13-8.

9. Expert Panel on Detection, Evaluation, and Treatment of High Blood Cholesterol in Adults. Third report of the National Cholesterol Education Program (NCEP) (Adult Treatment Panel III) Final Report. Circulation. 2002;106:3143-421.

10. Isomaa B. A major health hazard: the metabolic syndrome. Life Sci. 2003;73:2395-411.

11. Puccio EM, McPhillips JB, Barrett-Connor E, Ganiats TG. Clustering of atherogenic behaviors in coffee drinkers. Am J Public Health. 1990;80:1310-3.

12. Pedersen BK, Saltin B. Evidence for prescribing exercise as therapy in chronic disease. Scand J Med Sci Sports. 2006;16(Suppl 1):3-63.

13. Tuomilehto J, Hu G, Bidel S, Lindström J, Jousilahti P. Coffee consumption and risk of type 2 diabetes mellitus among middleaged Finnish men and women. JAMA. 2004;291:1213-9.

14. Stensvold I, Tverdal A, Foss OP. The effect of coffee on blood lipids and blood pressure. Results from a Norwegian cross-sectional study, men and women, 40-42 years. J Clin Epidemiol. 1989;42:877-84.

15. Jee SH, He J, Whelton PK, Suh I, Klag MJ. The effect of chronic coffee drinking on blood pressure: a meta-analysis of controlled clinical trials. Hypertension. 1999;33:647-52.

16. Jee SH, He J, Appel LJ, Whelton PK, Suh I, Klag MJ. Coffee consumption and serum lipids: a meta-analysis of randomized controlled clinical trials. Am J Epidemiol. 2001;153:353-62.

17. Greenberg JA, Axen KV, Schnoll R, Boozer CN. Coffee, tea and diabetes: the role of weight loss and caffeine. Int $\mathrm{J}$ Obes. 2005;29:1121-9.

18. Hino A, Adachi H, Enomoto M, Furuki K, Shigetoh Y, Ohtsuka $\mathrm{M}$, et al. Habitual coffee but not green tea consumption is inversely associated with metabolic syndrome. An epidemiological study in a general Japanese population. Diabetes Res Clin Pract. 2007;76:383-9.

19. Kemper HC, editor. Amsterdam growth and health longitudinal study: a 23-year follow-up from teenager to adult about lifestyle and health. Basel, Switzerland: Karger; 2004.

20. Sesso HD, Stampfer MJ, Rosner B, Hennekens CH, Gaziano JM, Manson JE, et al. Systolic and diastolic blood pressure, pulse pressure, and mean arterial pressure as predictors of cardiovascular disease risk in men. Hypertension. 2000;36:801-7.

21. Ferreira I, Henry RM, Twisk JW, van Mechelen W, Kemper HC, Stehouwer CD. The metabolic syndrome, cardiopulmonary fitness and subcutaneous trunk fat as independent determinants of arterial stiffness: the Amsterdam growth and health longitudinal study. Arch Intern Med. 2005;165:875-82.

22. Morriss R, Mohammed FA. Metabolism, lifestyle and bipolar affective disorder. J Psychopharmacol. 2005;19(6 suppl):94-101.

23. van Dusseldorp M, Katan MB, van Vliet T, Demacker PN, Stalenhoef AF. Cholesterol-raising factor from boiled coffee does not pass a paper filter. Arterioscler Thromb Vasc Biol. 1991;11:586-93.

24. Boekschoten MV, Engberink MF, Katan MB, Schouten EG. Reproducibility of the serum lipid response to coffee oil in healthy volunteers. Nutr J. 2003;2(1):8.

25. Boekschoten MV, van Cruchten ST, Kosmeijer-Schuil TG, Katan MB. Negligible amounts of cholesterol-raising diterpenes in coffee made with coffee pads in comparison with unfiltered coffee (in Dutch). Ned Tijdschr Geneeskd. 2006;52:2873-5.

26. Strandhagen E, Thelle DS. Filtered coffee raises serum cholesterol: results from a controlled intervention trial. Eur J Clin Nutr. 2003;57:1164-8.

27. Urgert R, Katan MB. The cholesterol-raising factor from coffee beans. Annu Rev Nutr. 1997;17:305-24.

28. Rosengren A, Dotevall A, Wilhelmsen L, Thelle D, Johansson S. Coffee and incidence of diabetes in Swedish women: a prospective 18-year follow-up study. J Intern Med. 2004;255:89-95.

29. van Dam RM, Feskens EJ. Coffee consumption and risk of type 2 diabetes mellitus. Lancet. 2002;360:1477-8.

30. Lopez-Garzia E, van Dam RM, Rajpathak S, Willett WC, Manson JE, Hu FB. Changes in caffeine intake and long-term weight change in men and women. Am J Clin Nutr. 2006;83:674-80.

31. Noordzij M, Uiterwaal CS, Arends LR, Kok FJ, Grobbee DE, Geleijnse JM. Blood pressure response to chronic intake of coffee and caffeine: a meta-analysis of randomized controlled clinical trials. J Hypertens. 2005;23:921-8.

32. Geleijnse JM, Kok FJ, Grobbee DE. Impact of dietary and lifestyle factors on the prevalence of hypertension in Western populations. Eur J Pub Health. 2004;14:235-9.

33. Stamler J, Caggiula AW, Grandits GA. Relation of body mass and alcohol, nutrient, fiber, and caffeine intakes to blood pressure in the special intervention and usual care groups in the Multiple Risk Factor Intervention Trial. Am J Clin Nutr. 1997;65(sup$\mathrm{pl}): 338 \mathrm{~S}-65 \mathrm{~S}$.

34. Winkelmayer WC, Stampfer MJ, Willett WC, Curhan GC. Habitual caffeine intake and the risk of hypertension in women. JAMA. 2005;294:2330-5.

35. Uiterwaal CS, Verschuren WM, Bueno-de-Mesquita HB, Ocké M, Geleijnse JM, Boshuizen HC, et al. Coffee intake and incidence of hypertension. Am J Clin Nutr. 2007;85:718-23.

36. Salazar-Martinez E, Willett WC, Ascherio A, Manson JE, Leitzmann MF, Stampfer MJ, et al. Coffee consumption and risk for type 2 diabetes mellitus. Ann Intern Med. 2004;140:1-8.

37. Hu G, Jousilahti P, Peltonen M, Bidel S, Tuomilehto J. Joint association of coffee consumption and other factors to the risk of type 2 diabetes: a prospective study in Finland. Int J Obes. 2006; 30:1742-9.

38. van Dam RM, Dekker JM, Nijpels G, Stehouwer CD, Bouter LM, Heine RJ. Coffee consumption and incidence of impaired fasting glucose, impaired glucose tolerance and type 2 diabetes: the Hoorn study. Diabetologia. 2004;47:2152-9.

39. Keijzers GB, de Galan BE, Tack CJ, Smits P. Caffeine can decrease insulin sensitivity in humans. Diabetes Care. 2002;25: 364-9.

40. Bos MB, de Vries JH, Wolffenbuttel BH, Verhagen H, Hillege JL, Feskens EJ. The prevalence of the metabolic syndrome in the Netherlands: increased risk of cardiovascular diseases and diabetes mellitus type 2 in one quarter of persons under 60 (in Dutch). Ned Tijdschr Geneeskd. 2007;151:2382-8. 